\title{
PROVISION OF NECESSARY TEACHING AND LEARNING NEEDS FOR IMPROVING ACADEMIC PERFORMANCE OF STUDENTS WITH VISUAL IMPAIRMENT IN TANZANIA INCLUSIVE SECONDARY SCHOOLS
}

\author{
Celestine D G Karuhawe ${ }^{1}$ \\ ${ }^{1}$ Department of Educational Psychology and Curriculum Studies, University of Dar es Salaam School of Education, Tanzania
}
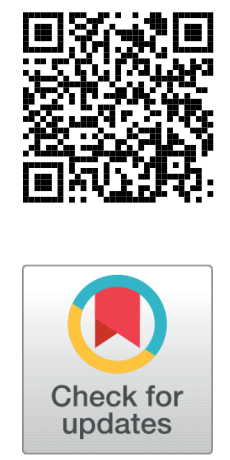

Received 24 February 2021

Accepted 11 March 2021

Published 30 April 2021

Corresponding Author

Celestine D G Karuhawe, email:kar

uhawe68@gmail.com

DOI $10.29121 /$

granthaalayah.v9.i4.2021.3726

Funding: This research received no specific grant from any funding agency in the public, commercial, or not-for-profit sectors.

Copyright: (C) 2021 The Author(s). This is an open access article distributed under the terms of the Creative Commons Attribution License, which permits unrestricted use, distribution, and reproduction in any medium, provided the original author and source are credited.

\section{ABSTRACT}

This paper focuses on provision of necessary teaching and learning needs for improving academic performance of students with visual impairment studying in inclusive private as well as public secondary schools in Tanzania. It was guided by the following three specific objectives: to analyse reasons for providing necessary teaching and learning needs of students with visual impairment in Tanzania inclusive secondary schools; to assess types of teaching and learning needs that are necessary in provision of education for VI students in Tanzania inclusive secondary schools; to highlight significance of providing necessary teaching and learning needs to students with visual impairment in Tanzania inclusive secondary schools.

The Open System's Model was adapted in conducting this study. The model provides pieces of advice for provision of education under the following stages: input, process, and output to enable students learn efficiently as well as perform better in studies and examinations. In its pursuit, the study applied qualitative research approach and a case study design. Qualitative research approach and the case study allowed the researcher to avoid biases by supporting researched information with clear facts as advised in rules of credibility, transferability, dependability, and confirmability. Twenty-four participants selected under purposive sampling procedure were involved in the study. Semistructured interviews and focus group discussions were the employed data collection methods. The researcher insists that necessary teaching and learning needs should always be provided in Tanzania inclusive secondary schools for students with visual impairment. Their significance is to facilitate students' lesson understanding and better performance in examinations. Good examination results will assure parents and the government on extent to which education provided in the country meets intended national goals. It should be maintained by making provision of such needs a continuous process. 
Keywords: Performance, Moest, Students with Visual Impairment, Subjects, VI Students, Baed, Maed, And Secondary Schools

\section{INTRODUCTION}

\subsection{BACKGROUND INFORMATION}

This paper provides information on provision of necessary teaching and learning needs for improving academic performance of students with visual impairment studying in inclusive private and public secondary schools in Tanzania. Its background highlights how provision of these needs facilitate learning of such students because they lead them to better performance in studies and examinations.

Part of background is presented followed by rationale of the study, statement of the problem, main objective of the study, specific objectives of the study, research questions and theoretical framework. Other parts include research methodology, generalisability of the study, data presentation and discussion. The paper ends up with strengths and weaknesses behind provision of necessary teaching and learning needs as well as summary, conclusions and recommendations.

\subsection{THE CONCEPT OF PROVISION OF NECESSARY TEACHING AND LEARNING NEEDS FOR IMPROVING ACADEMIC PERFORMANCE OF STUDENTS WITH VISUAL IMPAIRMENT}

The concept "provision of necessary teaching and learning needs for improving academic performance of students with visual impairment" refers to all basic needs of education, which if provided, enable students perform better in studies and subject examinations administered in schools. It is stated by Lugome (2018) as well as Possi and Milinga (217) that formal education from which such needs are provided to enable students perform better, was introduced at first in Tanzania in 1950. In that year, Buigiri primary school for boys with visual impairment was established by the Anglican Church from Britain. The very school started to enroll girls with visual impairment in 1983. It is further portrayed by Chawala (2011) that in 1960, the first student from that school was enrolled at Mpwapwa secondary school. As days went on, more students got enrolled for primary and secondary education in other schools established later in different regions of the country.

In view of Said (2017), From the time Buigiri Primary school was established and in other schools established in other regions, the necessary teaching and learning needs for improving academic performance of students with visual impairment, used to be provided by the government in inclusive schools when it got them in form of aid from donor countries. In rare cases, it used to solicit funds, which met costs for purchasing few items supplied in inclusive schools. The government involved itself in this low commitment to provision of such needs although provision of necessary 
teaching and learning needs was regarded relevant in enabling students perform better in studies and examinations. Despite existence of such unreliable means for providing teaching and learning needs to VI students, Kisanga (2017) and Lugome (2018) argue that when education is provided in absence of necessary needs to students, students end up attaining minimal achievements in education.

This paper advises provision of education to students with visual impairment in secondary schools supplied with necessary teaching and learning needs. Such needs will facilitate their learning, understanding of the subjects taught and better performance in subject examinations conducted.

\subsection{RATIONALE OF THE STUDY}

The inclusive education system enrolling students with visual impairment in public and private secondary schools in the country has not made much progress because students have been failing in their examinations. As a result, majority have been unable to proceed with further education and benefit from the studies conducted. King (2014) commented that secondary education is meant to equip students with technical skills, which will make them capable of facing challenges of the world or the environment in which such education is offered. Since education offered was and has not been meeting all these requirements, it implies that it has been of low quality. It results from providing insufficient knowledge in the subjects taught as well as the situation of not providing all other necessary teaching and learning needs to students. If left to continue, the trend may adversely affect the quality of education for the said students and they would go on failing in national examinations. To resolve the problems, the government should establish many schools not only for increasing students' enrollment but also for putting much emphasis on providing them with high quality education. In due regard, such education should be provided in presence of all necessary teaching and learning needs

in schools to facilitate students' understanding in lessons taught and in performing better the subject examinations conducted.

\section{STATEMENT OF THE PROBLEM}

It is stated in many studies that students with visual impairment in Tanzania secondary schools are provided with low quality inclusive education due to shortage of the required inclusive teaching and learning needs to facilitate their subject understanding and better performance in examinations (Kisanga, 2017; Lugome, 2018; Watch, 2017). Shortage of these teaching and learning needs in schools is mainly caused by the government's low commitment in assessment of lacking needs for VI students, purchase as well as furnish them in schools without allowing conscious and unconscious isolation of students with visual impairment when distributing them to students in schools (Bhallalusesa, 2012; ) (Lugome, 2018). 
The problem retards learning abilities of students with visual impairment by making them fail in final examinations (Kisanga, 2019; POSSI \& MILINGA, 2017). Moreover, such situation makes them remain marginalized in the education sector thereby preventing them from proceeding with further studies, competing effectively in the labour market, developing their independence for better living in future, and benefiting from other advantages of studying secondary education (King, 2014; Kisanga \& Richards, 2018).

This study looked on how provision of necessary teaching and learning needs was important in facilitating lesson understanding and better performance in examinations in Tanzania secondary schools among VI students. It also assessed types of needs which had to be provided in order to enable students learn and attain good results from studying.

\section{MAIN OBJECTIVE OF THE STUDY}

The main objective of this study was to assess necessary teaching and learning needs provided to facilitate pertinent acquisition of education among VI students in Tanzania secondary schools.

\subsection{SPECIFIC OBJECTIVES OF THE STUDY}

The study had the following specific objectives:

1. To analyse reasons for providing necessary teaching and learning needs of students with visual impairment in Tanzania secondary schools;

2. To assess types of teaching and learning needs that are necessary in provision of education for VI students in Tanzania secondary schools;

3. To highlight significance of providing necessary teaching and learning needs to students with visual impairment in Tanzania secondary schools.

\subsection{RESEARCH QUESTIONS}

The following research questions guided this study:

1. What are reasons for providing necessary teaching and learning needs to students with visual impairment in Tanzania secondary schools?

2. What are types of teaching and learning needs that are necessary in provision of education for VI students in Tanzania secondary schools?

- What is significance of providing necessary teaching and learning needs to students with visual impairment in Tanzania secondary schools?

\section{THEORETICAL FRAMEWORK}

This study was guided by the Open System's Model originally developed by Ludwig von Bertanlanffy in 1956. According to Mizikaci (2018), Ludwig von Bertanlanffy, 
a biologist, discovered how systems found in a body of living organisms functioned cooperatively to make the organisms live comfortably. Mizikaci (2018) proclaims that a short time thereafter, the discovery was seen applicable across all disciplines such as education studies. The modelstresses that in providing education, there are three main stages to be considered, namely, inputs, process and outputs. In view of Hoy and miskel (2008), provision of education under these stages was capable of enabling involved schools provide education with high quality because by teaching students under input stage, they could be supplied with basic teaching and learning needs in facilitating teaching, students' lesson understanding and better performance in examinations. Hoy and miskel (2008) go on stating that during the process stage, materials and other supplied needs could be clearly worked on to facilitate students' lesson understanding and better performance in examinations. Under output stage, good results could be witnessed as products of the previous two stages.

\subsection{ADVANTAGES AND DISADVANTAGES OF APPLYING THIS MODEL IN RESEARCH}

Information obtained in the study by Mfangavo (2015), proclaims that use of this model in research has got advantages and disadvantages. Advantages are that first, it motivates teachers in properly preparing lessons because they are forced to teach subjects by following three stages of inputs, processes and outputs. Second, the model facilitates students' lesson understanding, for they get education in schools supplied with basic needs and teachers designing as well as applying clear teaching and learning instructional strategies.

On the other hand, the disadvantages portrayed by this scholar in applying the system's model in research include one, causing teachers to find teaching as highly time consuming due to too much preparations before lesson presentations. Two, by requiring schools have basic needs and employing efficient teachers in properly preparing lessons, the situation makes education administrators to find school running aspect very expensive.

Despite the disadvantage expressed with regard to applying open system's model in research, its advantages were seen strong enough to enable students acquire expected education achievements during and after schooling. The input stage, for instance, is found good in emphasizing on importance of supplying in schools, relevant teaching and learning needs. The students taught by well-prepared teachers before teaching in schools supplied with necessary teaching and learning needs understand subjects clearly and thus, perform better in final examinations as well as in life after schooling. Therefore, the model was found important for being applied in this study. 


\subsection{RESEARCH METHODOLOGY}

\subsubsection{RESEARCH DESIGN AND DATA COLLECTION METHODS}

The study was conducted under qualitative research approach through a case study design. The research approach and study design were selected in relation to an advice by Bryman (2016), Communication Skills scientific publishing (2008) and Yin (2011). They view the two research aspects to have an advantage of providing an opportunity to respondents in giving views without limit and clarify them to an extent of enabling the researcher collect clear in-depth information. The case study was further seen relevant for this study since it is the only design capable of allowing studies focusing on a single group of people such as secondary school students with visual impairment. Moreover, the selected approach and design enabled the researcher to conduct interviews and focus group discussions that were not limited to particular questions. As submitted by Creswell (2014), the researcher in using said research methodology pathways was able to redirect or guide questions to facilitate understanding. Additionally, the study conducted in relation to qualitative approach and case study design, in view of Lincoln and \&amp;guba (1985) , allows application of credibility, transferability, dependability, and confirmability. These are principles applied by putting supporting facts to all information obtained in the research field or in writing final report in order to prevent the researcher from including biased data in information read by the audience. All these situations enabled the researcher to collect enough data which were easy for him to analyse in final report.

\subsubsection{STUDY AREA, TARGET POPULATION AND SAMPLE SELECTION}

The study was conducted in four administrative regions of Dar es Salaam, Dodoma, Mwanza and Tabora. With the exception of Ministry of Education, Science and Technology (MoEST) officials found only in Dodoma, the regions had four secondary schools each with target population out of which the rest of participants for the study were selected. They included school heads, general education teachers, specialists, teachers with visual impairment and secondary school students.

Table 1 Sample Distribution

\begin{tabular}{|ccc|}
\hline $\begin{array}{c}\text { S/N with the identified types of } \\
\text { respondents consulted }\end{array}$ & $\begin{array}{c}\text { School/organisation with } \\
\text { its respondents }\end{array}$ & $\begin{array}{c}\text { The sampling } \\
\text { technique applied }\end{array}$ \\
1. MoEST officials & MoEST-2 & Purposive \\
School heads -GT-TVI-SP-SVI and NDs & Mkolani-1 school head-1 & Purposive \\
& GT-1 Sp-2 SVI-1 NDs. & \\
& Mvumi-1 school head-1 GT-1 & \\
& Tvi-1 SP-2 SVI. Tusiime-1 & \\
& school head-1 GT-2 SVI-1 & \\
& NDs. Tabora Girls-1 school & \\
& head-1 GT-2 SVI-1 TVI. & \\
\hline
\end{tabular}


Purposive sampling technique was applied in selecting a sample of 24 participants from the mentioned target population. Selection was done by considering persons who shared more or less common occupation and had worked on education provision to VI students in private and public secondary schools or in the Ministry of Education for at least three years. The participants sharing common occupation with good working time experience, enabled the researcher to collect in-depth data that answered all research questions. Their selection was in line with Cohen et al. (2011) . They advice that selection of research participants should be for those with adequate knowledge on the given research problem. Distribution of the selected sample is indicated in Table 1.

Key:

GT: General Teachers

TVI: Teachers with Visual Impairment

SVI: students with visual impairment

SP: specialist

NDs: Non-disabled students.

Table 2 Qualifications of Selected Research Participants

\begin{tabular}{|c|c|c|}
\hline $\begin{array}{l}\text { S/N with the identified type } \\
\text { of qualification }\end{array}$ & $\begin{array}{l}\text { Selected participants with their } \\
\text { qualifications }\end{array}$ & $\begin{array}{c}\text { Gender } \\
\text { consideration }\end{array}$ \\
\hline \multirow[t]{3}{*}{ 1. Access to education } & $\begin{array}{c}\text { School heads, GT, SP, TVI, MoEST officials: } \\
12 \text { Bachelors degree and two Masters' } \\
\text { degree holders }\end{array}$ & $\begin{array}{l}\text { Nine men and } 5 \\
\text { women }\end{array}$ \\
\hline & $\begin{array}{l}\text { MoEST officials: } 1 \text { Bachelor's degree holder } \\
\text { and } 1 \text { Masters' degree holder }\end{array}$ & Males \\
\hline & $\begin{array}{l}\text { SVI and NDs: } 5 \text { form four learners and } 5 \\
\text { form three others }\end{array}$ & $\begin{array}{l}5 \text { girls and } 5 \\
\text { boys }\end{array}$ \\
\hline \multirow[t]{2}{*}{$\begin{array}{l}\text { 2. Experience of } \\
\text { working/assisting students } \\
\text { with visual impairment }\end{array}$} & $\begin{array}{c}\text { School heads, GT, SP, TVI, MoEST officials: } \\
\text { Between } 3 \text { and } 15 \text { years }\end{array}$ & $\begin{array}{l}\text { nine were men } \\
\text { while women } \\
\text { were five }\end{array}$ \\
\hline & $\begin{array}{l}\text { SVI and non-disabled students: between } \\
\text { three and four years. }\end{array}$ & $\begin{array}{c}\text { Girls were } 5 \text { and } \\
\text { boys were also } \\
5 .\end{array}$ \\
\hline \multirow[t]{2}{*}{ 3.Age qualification: } & $\begin{array}{l}\text { School heads, GT, SP, TVI, MoEST officials: } \\
\text { Ranged between } 30 \text { and } 50 \text { years }\end{array}$ & $\begin{array}{l}\text { Men were nine } \\
\text { while women } \\
\text { were } 5\end{array}$ \\
\hline & $\begin{array}{l}\text { SVI and NDs: Ranged between } 16 \text { and } 18 \\
\text { years }\end{array}$ & $\begin{array}{l}\text { Girls were } 5 \text { and } \\
\text { boys also } 5\end{array}$ \\
\hline
\end{tabular}

Table 1 indicates all twenty-four participants selected from secondary schools found in sampled schools as well as those selected from the Ministry of Education, Science, and Technology. Four were general education teachers, two teachers with visual impairment and two specialists (Table 1 ). One teacher with visual impairment was selected to represent public secondary schools and another one for private schools (Table 1 ). The same was done for the specialists consulted in this study 
whereby one represented public secondary school while another one represented private secondary school (Table 1 ). Other respondents were eight students with visual impairment and their fellow two non-disabled students who assisted VI students as human readers (Table 1 ). Two students with visual impairment represented each sampled school (Table 1 ). One non-disabled student was selected to represent public secondary schools and another one for private secondary schools (Table 1 ). There were also four school heads each one representing one sampled school. Two officials represented MoEST (Table 1 )

shows that all 24 research participants had enough qualifications in providing data for the study. The qualifications included access to enough education, experiences for working on issues of visual disability, and assisting VI students as human readers. In the sampled schools, some non-disabled students volunteered as human readers for VI students in reading for them on materials published in ink-writings.

\subsubsection{GENERALISABILITY OF THE STUDY}

Based on analysis submitted by Cohen et al. (2011), Creswell (2014), and Yin (2011), qualitative research approach, was applied in this study and thus, its findings can be generalised to other school settings with similar characteristics of the sampled schools. This makes the study valuable to VI students studying in public and private secondary schools faced with challenges such as shortage of teaching and learning needs, specialists, and provision of insufficient knowledge when teaching some subjects to students.

\section{PRESENTATION AND ANALYSIS OF STUDY FINDINGS, INTERPRETATION AND DISCUSSION}

The findings reached in this section, are products of the research conducted in relation to open system's model from which the theoretical framework of this study originated. The findings are presented and analysed under three major parts followed by another part on interpretation and discussion.

\subsection{REASONS FOR PROVIDING NECESSARY TEACHING AND LEARNING NEEDS FOR STUDENTS WITH VISUAL IMPAIRMENT IN TANZANIA INCLUSIVE SECONDARY SCHOOLS}

14 (58.33\%) participants among school heads, MoEST officials, and students with visual impairment, through semi-structured interviews and focus group discussions, were exposed to the research question requiring them to explain reasons with regard to provision of special necessary teaching and learning needs for improving academic performance of the students in Tanzania inclusive secondary schools.

The MAEd female school head1, when asked why should VI students in inclusive schools be provided with special necessary teaching and learning needs, said that, 
"The reason is to enable them understand lessons in the way non-disabled students who are the majority, understand lessons."

The BAEd male MoEST official2, in giving more reasons for provision of necessary special teaching and learning needs for VI students in schools, stated that, "It is because the subjects taught in inclusive classrooms, are originally designed to be understood to non-disabled students and not for students with special needs. This makes most of the teaching and learning needs unfriendly in learning for VI students."

\subsection{THE NECESSARY TYPES OF TEACHING AND LEARNING NEEDS IN PROVISION OF QUALITY EDUCATION FOR VI STUDENTS IN TANZANIA INCLUSIVE SECONDARY SCHOOLS}

In this study section, participants were exposed to interviews and focus group discussions that probed for the Necessary Teaching and Learning Needs Facilitating Provision of quality Education for VI Students in Tanzania Secondary Schools. In analyzing gathered findings, ways in which needs were utilized for successful learning of VI students were also disclosed. The findings were as follows:

\subsubsection{AVAILABILITY OF VARIOUS PROFESSIONALS IN INCLUSIVE SCHOOLS}

This was $\mathrm{n}$ important need in facilitating learning for students with visual impairment. It was presented by $16(66.67 \%)$ research participants consisting of general teachers, teachers with visual impairment, specialists, and students with visual impairment. On presenting the need through interviews and focus group discussions, they revealed on availability of professionals in various aspects as need of vital importance. It is because each of them had a specific responsibility to perform in facilitating learning for students with visual impairment in schools.

From explanations provided by MAEd female school head1, it was disclosed that,

"The needed groups included professionals in Braille (also known as specialists), professionals in counselling, mobility training and teachers of different class subjects. From professions possessed by persons in this group, various activities are performed for smooth provision of inclusive education to students with visual impairment."

The BAEd male TVI2, added that, "Professionals such as those in Braille, are key people in transcribing materials, which are in ink-writings so that by putting them into Braille, they can easily be read by VI students."

The BAEd female GT2 viewed out that, "Mobility training was an additional activity performed by professionals in Braille. They taught VI students on how to go in different school compounds whenever they thought of going in different school environments to solve various needs."

The BAEd female SP1, when asked to verify if VI students were getting counselling on various aspects related to school studies, stated that, "Counselling as an activity is performed in school by Braille professionals and any interested general education 
teacher. Its significance is to abolish fear and the state of despairing instead of continuing with studies courageously."

A form four female SVI5, when asked to identify other professionals needed in provision of inclusive education to VI students, stated that, "Teachers of different class subjects are needed for teaching various subjects, composing examinations and marking them to evaluate students' academic progress."

\subsubsection{AVAILABILITY AND IMPORTANCE OF SPECIAL TEACHING AND LEARNING MATERIALS AS WELL AS READING AND WRITING FACILITIES}

During focus group discussions and interviews, 12 (50\%) of the respondents, including non-disabled students and those with visual impairment as well as the MoEST officials, identified availability of a variety of teaching and learning materials in Tanzania secondary schools as a unique need in provision of quality education to students with visual impairment.

When asked to identify needed types of materials with their significance in provision of quality inclusive education for VI students, the MAEd male MoEST official1 stated that, "The materials such as efficient furniture in classrooms, facilitate learning as they make students have where to sit and place writing machines including other learning materials. Diagrams and maps drawn in Braille, are also needed for facilitating lesson understanding."

A form three male NDs1 added that, "Other teaching and learning materials, which, if provided, facilitate learning of students with visual impairment, include books written in Braille, magazines and other newspapers written in Braille."

On the other hand, some general education teachers, specialists and teachers with visual impairment who were exposed to focus group discussions, came up with using Internet searched materials as the most efficient need that had to be encouraged if possible, rather than providing in schools hard-copy related materials.

The BAEd male GT3 in that concern, had these to say, "Materials accessed through Internet are many and possibly more modern than books printed in Braille."

In that statement, the participants concurred with the argument made by Kisanga and Kisanga (2020). They affirm that materials accessed through computer assistive technologies are found more useful to VI students than printed Braille materials, for they are highly current and available in any place provided the student knows how to use internet system.

The study results by six (25\%) participants among MoEST officials, specialists and teachers with visual impairment, indicated that various special writing and reading facilities were also considered important in providing quality inclusive education for students with visual impairment in Tanzania secondary schools. They identified typewriters, computers and Braille writers to be the most crucial of all facilities.

The BAEd male Sp2 on availability of these facilities as basic needs, said that:

Typewriters and computers are needed in the learning of students with visual impairment because they enable them produce writings in ink, the aspect, which con- 
nects them easily with general teachers. All do not have skills of reading and writing Braille, the special writings used by VI students in learning.

The MoEST BAEd male official2, being aware of various teaching and learning needs of VI students, added that, "On top of typewriters and computers, efficient learning of these students requires additional facilities such as Perkins Braillers, Marburg frames, and Braille interlining frames."

\subsection{SIGNIFICANCE OF PROVIDING NECESSARY TEACHING AND LEARNING NEEDS TO STUDENTS WITH VISUAL IMPAIRMENT IN TANZANIA INCLUSIVE SECONDARY SCHOOLS}

Moreover, 14 (58.33\%) participants among school heads, MoEST officials and students with visual impairment were exposed to research questions through semistructured interviews and focus group discussion that wanted them to explain significance of providing necessary teaching and learning needs to students with visual impairment in Tanzania inclusive secondary schools.

The BAEd male school head2 explained one of such significances as being, "To strengthen ability of VI students in managing to pursue their studies as planned by the nation."

The form four female SVI5, when asked about significance resulting from providing necessary teaching and learning needs for VI students stated that, "Provision of these needs prevents students with visual impairment from being nicknamed as an exceptional examination failing community in schools.

\subsection{INTERPRETATION AND DISCUSSION OF FINDINGS}

Interpretation and discussion made in this part, covers the three sections, which presented and analysed data in relation to specific objectives and research questions of the study. Consequently, it works on reasons for providing necessary teaching and learning needs, their types, and significance of providing them in providing quality education to students with visual impairment in schools.

Data presented on the first section substantiated that provision of necessary special teaching and learning needs for such students in Tanzania secondary schools is relevant due to reasons for doing that. From what respondents said, there are three major reasons. The first one results from the tendency of general teachers who, by regarding students with visual impairment as a clique among many students existing in inclusive classrooms, are not conscious enough to understand whether or not the students have their own teaching and learning needs or they can as well use common needs prepared for non-disabled students. The general teachers' view of not knowing what to do with regard to teaching VI students, was submitted previously by Omvig (1999) and Karuhawe (2020). They write that some problems that face students with visual impairment in learning emanate from wrong conceptions of several teachers on learning styles of VI students. For example, in view of Omvig (1999), there are those who think that the students have their own means for study- 
ing using skills acquired in their former schooling. Teachers with these thoughts cannot take trouble of doing anything good of enabling the students learn efficiently. Secondly, others cannot offer any assistance due to their misbehaviors, which force them to entertain the habit of taking little care of students they understand to be with disabilities. Still others are found doing ways they think good for such students due to lack of knowledge on how to teach them. Teachers with these feelings are reported by Lugome (2018) and Bhalalusesa (2012) to reach the extent of unconsciously or consciously isolate VI students from supplying them with teaching and learning materials distributed to other students in inclusive classrooms. According to Kisanga (2017, what happens after that is to find every student with visual impairment struggling for his/her own in obtaining the materials facilitating learning.

The second reason necessitating provision of special needs to VI students seems to have been clearly analysed by Parvin (2018). It states that the subjects taught in inclusive classrooms are originally designed to be understood to non-disabled students and not students with special needs. That problem makes curriculum developers to suggest and even supply in schools, most of the teaching and learning needs, which are unfriendly in the learning of students with special needs. Respondents pointed an example that most curriculum developers are used to know much about use of exercise books, ink-written texts and ink-writing pens in learning. These materials have nothing to do with learning of VI students who learn by writing with Perkins Braillers on manila papers. Also, they produce writings with typewriters or computer printers using duplicating papers. Furthermore, the students read Braille texts instead of ink-written texts.

The third reason explaining about VI students to be provided with special teaching and learning needs is generally to facilitate performance of students in studies and examinations. From respondents' explanations, it was pointed out that as long as better performance in studies and examinations are considered the only criteria identifying students to have clearly succeeded in learning, provision of necessary needs is fundamentally undertaken to enable them reach this target. This reason supports the analysis by MoEST (2014). It comments that students' passing in examinations is a key academic achievement qualifying them for being selected in joining further studies.

Therefore, provision of Necessary Special Teaching and Learning Needs for VI students is seen the best decision as the needs provided had to be assessed firstly, to determine their efficiency in facilitating learning of the students. Secondly, the needs enable students to clearly understand the taught subjects and later perform better in examinations administered.

From the first section, interpretation and discussion are centred on types of teaching and learning needs provided in Tanzania inclusive secondary schools. In that regard, availability of professionals in various aspects was presented and analysed by respondents as the most significant need. It is because each professional has an activity to perform for smooth provision of that education. 
Professionals in Braille (also known as specialists) are seen as key people in provision of education for VI students. In the first place, they are the only professionals capable of transcribing examinations composed by general education teachers of different subjects. Examinations are administered at different school times and routines. Respondents stated that examination administration took place a short time before the end of the term. As a result, since schools perform activities in two terms per annum, two types of examinations are administered. Terminal examinations are organised before the end of the first term, while the second type, referred to as annual examinations, are conducted at the end of the second term. Each of these examinations has to be transcribed into Braille by these professionals.

Periods of conducting secondary school examinations in Tanzania are in line with observation by Njabili (1999). In that observation, she discloses that schools have a culture of organizing formative evaluation by conducting terminal examinations and summative evaluation through organizing annual examinations.

Respondents stated further that transcription into Braille, takes place when general education teachers plan to administer tests during the first and second terms before exposing students to major terminal examinations. The professionals are supposed to transcribe all tests and examinations to be administered to enable students read questions as well as understand them by themselves instead of listening to someone reading for them. Transcription is of great help since the act of listening to someone reading denies students enough time of concentrating and brainstorming the questions asked before answering them.

Another important responsibility of professionals in Braille is to transcribe handouts for students with visual disability. Some general education teachers are used to prepare notes, which are later distributed to students in order to be copied in their exercise books or photocopied and thereafter, preserved in their files. Teachers prepare notes in their efforts of supplementing scarcity of references or textbooks to resolve the acute problem of both of the mentioned types of scripts in the sampled schools. Preparation of hand-outs is further considered important in summarizing some references consulted to consolidate understanding of subjects taught in classrooms. Although providing hand-outs to students is opposed by administrators who regard it as an illegal act, however, according to respondents, provision of hand-outs, to the large extent, helps students in learning because they are written in simple language that teachers think are clear to their students. Teachers and other professionals who prepare notes to students with visual impairment are chiefly concerned to have more positive attitude towards presence and learning capabilities of students with visual impairment than those who cannot do that. Added to that, they are characterized as teachers with high command in mastering their class subjects and learning methods.

Furthermore, the participants analysed that transcription into ink-writings, especially in School B of the private sector is additionally done in Braille written tests and examinations for students. The process enables responsible subject teachers to 
clearly mark students' works using Braille transcribed answer-sheets, which are in ink-writings from Braille writings produced before by students.

Also, professionals in Braille have a responsibility of marking the works of students done in Braille. Such direct marking of the Braille answer-sheets of students in other sampled secondary schools is undertaken differently from the way it is done in School B. In such schools, specialists mark Braille written works of students using marking schemes prepared in advance by subject teachers concerned. Thereafter, the specialists give back the marked answer-sheets to responsible subject teachers who then hand them over to students.

Moreover, Braille professionals teach Braille alphabets and writings to students with visual impairment possessing low Braille skills in writing and reading. In view of the research participants, such students' visual disability is always detected while in secondary schools or a short time before completing primary school education. Besides, Braille learning involves students, whose primary school teachers did not adequately teach them to cover both English Braille Grades 1 and 2. According to Cowan (2015), English Braille Grade 1 refers to English Braille written without including short-cuts. Each word under this grade is written with all letters making up the word. The English Braille Grade 2, on the other hand, refers to a system of writing Braille by including the short-cuts to various words accepted internationally to be written that way.

Moreover, it is learned that Braille professionals have enough skills in teaching typing and they are prepared for teaching computer literacy skills as well to the very students. According to respondents' explanations, professionals in Braille learn typing and computer literacy skills when they were in teachers' training colleges in which they learned Braille. Elementary knowledge on such courses was geared towards empowering them with ability of introducing skills to newly identified students with visual disability in schools.

The study results from respondents among teachers with visual impairment and specialists disclosed that professionals in Braille, had also studied the course on mobility training. It is applied in orienting students with visual impairment who are newly enrolled in schools. According to Lahav et al. (2015), mobility training involves walking with the newly enrolled students with visual impairment in new environments. The purpose is to enable students know their environment and start walking by themselves whenever they think of solving their immediate problems requiring them reach a given place. Professionals in Braille do that whenever they receive new students with visual impairment in their schools. Under the aid of a white-cane, such training is compulsory since in view of Lahav et al. (2015), students with visual impairment are characterized by not knowing environment they are exposed to for the first time.

The study results kept on showing that availability of professionals in counseling is another basic need in provision of quality inclusive education for VI students in secondary schools. From what they said, professionals with this knowledge are 
needed, particularly to newly infected students with visual impairment because they still have little experience in copying with that disability. They all need psycho-social support type of counseling, which, according to Chawala (2011) and Mgumba (2018), is aimed at making students who have acquired visual impairment accept their disability.

From what was specifically said by respondents on the side of teachers with visual impairment and specialists, students who become visually impaired at old age find themselves losing hope of earning a living. There are some students who reach the extent of thinking of committing suicide as a solution to the problems they are facing from the disability. Counseling is the solution for them to have new hope of continuing to live on earth.

Furthermore, respondents remarked that counseling was of great help to students with despair from continuing with studies after facing difficulties in studying. The problem of scoring low marks in tests and examinations, little understanding of subject-matters due to problems of not mastering English language very well, and complicated lesson presentations of some teachers are examples of hardships experienced by students. When problems are reported to responsible individuals, professionals in counselling intervene. Their interventions, according to respondents, take place whereby some students confidentially consult the professionals for advice or counselling. However, the nature of some students causes not all of them to consult counsellors due to fear. The professionals who are also teachers intervene by directly calling in their offices the affected students for counselling purposes. They do that to students, whose scores in school tests and examinations, are low and problematic and can afterwards lead students to poor performance in final national examinations.

The study results from respondents showed further that availability of teachers possessing knowledge on various subjects offered in Tanzania secondary schools is another most crucial need for providing quality inclusive education for VI students. They are teachers, whose professionals qualify them for teaching secondary school students. They are supposed to play a decisive role in preparing clearly the needed lesson plans, lesson notes and teaching methods, which can lead them to efficient classroom presentations of given subjects. They are the very teachers who also plan and compose school tests as well as examinations preparing students for better performance in national examinations. For the same purpose, teachers facilitate lesson understanding of students by referring them to reading relevant textbooks and references supplementing knowledge obtained through teaching.

Qualifications that allow such teachers in living as staff members in surveyed secondary schools for this study, ranged between those holding a diploma or a Bachelor's degree from any accredited world university. Possession of these qualifications coincide with disclosure by Cosmas (2016). According to him, diploma is a minimum qualification level for teachers of Tanzania secondary schools while the highest might be the Master Degree. Based on Cosmas' (2016) views, teachers in the surveyed secondary schools have the required qualifications because they range 
between those holding the Bachelor's degree to those with Master Degree. Taylor (2016) argues that teachers dealing with disabilities should have additional three different classifications of skills. Firstly, they are supposed to be persons with experience of being general teachers. With the qualification, they are supposed to have knowledge on various teaching methods applied in teaching subjects of their specialisation to students with visual impairment. Secondly, they should possess techniques of curriculum adaptation for visual learning. With these techniques, they are expected to adapt and apply concepts, teaching methodologies, and materials from the original curriculum without distorting the meaning planned for being taught to non-disabled students. Thirdly, they are expected to know how to assess students with visual impairment on various skills that should be offered to them. The skills should be able to expose them to independent living, Braille reading, use of typewriters/computers with their assistive technologies, and career education on jobs they can afford. In a nutshell, presence of professionals on various aspects in schools is an important teaching and learning need in order to perform different responsibilities in assisting students with disabilities.

In working on interpretation and discussion on types of needs provided in schools to facilitate learning of VI students, sufficient teaching and learning materials as well as reading and writing facilities, were also covered. Under that aspect, respondents argued that success of quality inclusive education to students with visual impairment in Tanzania secondary schools, requires sufficient teaching and learning materials as well as reading and writing facilities. UNICEF (2000) shows that there is need for providing quality education to school children by supplying in schools the needs facilitating their learning. This UN agency insists that materials and facilities provided are those designed to prevent the children from learning efficiently. Materials identified by respondents are such as Braille books, Braille maps and diagrams as well as Braille magazines while the reading and writing facilities include Perkins Brailler, Marburg and Braille Interlining frames.

The Braille books needed to facilitate learning for VI students should be of books carrying titles and contents found in the ink-printed books used by non-disabled students. Availability of such books will enable subject teachers to require and urge both non-disabled students as well as those with visual impairment spend most of their time reading, memorizing or widening their scope of understanding of lessons taught in classrooms.

Braille maps and diagrams as other relevant teaching and learning materials needed have importance of facilitating understanding of geography and biology subjects among students with visual impairment. In Geography, maps facilitate students' understanding, particularly when they were used in showing big rivers, mountains, lakes, oceans, and areas with different types of rocks. Such maps also show areas with vegetation like Savannah and Equatorial Forests in Africa. Diagrams, on the other hand, facilitate understanding of biology related topics such as respiratory systems, excretory systems and an alimentary canal of a human being. The used maps and 
diagrams in teaching, existed in schools after being drawn by specialists in collaboration with some innovative general teachers who taught geography or biology in classes having students with visual impairment.

Braille magazines were noted to have additional importance in provision of quality education to VI students. Their availability was of special importance as they enabled students to access information which strengthened knowledge obtained from the subjects taught in classrooms. The respondents justified that by reading magazines and newspapers, students got new knowledge on various aspects, which facilitated their understanding where some contents read were related to subject topics learned in schools.

Through focus group discussions, the study results showed concern of providing students with suitable furniture in inclusive classrooms as another best need. The furniture provided included efficient special lockers for preserving writing and reading materials for VI students. Others included desks, tables, and chairs used by students when writing through typewriters, computers or Perkins Braillers. Availability of this list of furniture in schools, which were sampled for this study contradicted the findings by POSSI and MILINGA (2017). In their study, it was revealed that schools suffered much from insufficient desks, tables, and chairs. The situation made students to even perform poorly in academics. From what respondents of this study kept on explaining, the special lockers found within or around inclusive classrooms were used in preserving reading and writing materials used by students whenever needed immediately. The students with materials around were at once taken and used whenever needed. For example, the materials appeared helpful when some teachers administered quizzes abruptly to evaluate the students' understanding level on subjects taught even if they had not been given time to prepare themselves for that. The teachers administered quizzes also for the purpose of preventing truancy of some students in school. In due regard, for absentees when the quiz was administered had no means of getting marks awarded to students who were present. Therefore, for clear provision of quality inclusive education for students with visual impairment in Tanzania secondary schools, providing them with relevant furniture in accommodating their study materials was the best need. It assured security of such study materials and prevented them from being affected with dust or rain.

The findings on importance of teaching and learning materials in facilitating learning of VI students in schools, concur with remarks by Cowan (2015). The author urges teachers to always provide relevant materials for their learning. In the findings from this study, it was noted that some general education teachers in the surveyed secondary schools, through sympathy, were not taking actions against students with visual impairment who sometimes made mistakes of not complying to teachings presented by teachers in using the analysed teaching and learning materials. That was a blunder made by teachers because it reinforced the habit of students to continue making mistakes after knowing that no steps would be taken against them. 
On top of teaching and learning materials, availability of typewriters, computers and Braille writing facilities was also seen crucial in providing quality inclusive education for the students. In participants' view, the secondary schools enrolling VI students are largely composed of general teachers. By producing ink writings using the facilities, the students enable general teachers to easily read and mark subject tests as well as examinations answered by the students. Perkins Brailler, Marburg and Braille Interlining frames, are further noticed important as they enable students to write notes read on their own whenever they prepare for tests and examinations through reading subject notes taught in classrooms.

The last part of this section deals with interpretation and discussion on significance of providing necessary teaching and learning needs to students with visual impairment in Tanzania inclusive secondary schools. Under this concern, findings justified that there are some significances with regard to provision of such needs. From explanations provided by respondents, one of these significances is to strengthen ability of VI students in managing to pursue their studies as planned by the nation. Here, from good performance by students resulting from provided needs, they are enabled to contribute for national development through managing to work on various development activities. This significance supports the study by Karuhawe (2020). It substantiates that VI students performing better in examinations after joining further studies from secondary school's secure employments from which some money generated is partly used in fostering development of the nation.

Secondly, provided needs had the significance of preventing students with visual impairment from being nicknamed as exceptional examination failing community in schools. Respondents who provided this significance clarified that in inclusive schools where school administration does not struggle hard for providing needs facilitating lesson understanding and better performance in examinations, make VI students to always perform poorly in the two aspects rather than the rest in school. That makes non-disabled students performing better to nickname VI students as "exceptional school failing community."

\subsection{STRENGTHS AND WEAKNESSES BEHIND PROVISION OF NECESSARY TEACHING AND LEARNING NEEDS TO STUDENTS WITH VISUAL IMPAIRMENT IN TANZANIA SECONDARY SCHOOLS}

Concerning strengths, the paper has clearly presented essential teaching and learning needs in provision of quality inclusive education for students with visual impairment in Tanzania secondary schools. If adequately provided, can enable VI students cope very well in learning with non-disabled students by clearly understanding lessons, performing better in examinations and going for further studies. They can above all, access better living in future.

About weaknesses, since it has been revealed that many of these needs can only be met by incurring much expenses, it is possible for private sector and the government to find it difficult from providing required amount of such needs in schools. The 
situation can limit opening of special units influencing enrollment of VI students in the country and make their majority remain in villages uneducated.

\section{SUMMARY, CONCLUSION AND RECOMMENDATIONS}

\subsection{SUMMARY AND CONCLUSIONS}

Investigation of necessary teaching and learning needs facilitating learning of students with visual impairment revealed many results including one, availability and importance of professionals in schools. Two, availability and importance of special teaching and learning materials plus reading and writing facilities. These needs, which are supplemented further by some other needs found within their paragraphs, are clearly interpreted, analysed, and discussed as needs with ability of facilitating better performance of VI students in studies and in examinations conducted. The situation provides qualification for students to join for further studies and later benefit from acquired education by enjoying better living in future.

The paper concludes that special teaching and learning needs should always be provided to students in schools. It is because the needs facilitate their learning as well as facilitating their better performance in examinations and in activities enabling them to earn their living in future.

\subsection{RECOMMENDATIONS}

From information revealed in the study, three types of recommendations were developed.

\subsubsection{RECOMMENDATIONS FOR ACTION}

It is recommended that firstly, provision of necessary teaching and learning needs should always be done in inclusive secondary schools enrolling students with visual impairment. The measure will enable them learn with success and continuing to perform better. Secondly, with that intention, the short courses teaching importance of providing relevant teaching and learning needs, where and how to obtain them should be continuously conducted. Thirdly, additional economic costs thought to appear in conducting trainings motivating provision of relevant teaching and learning needs in inclusive schools should not stop the process. Their benefits are of unique importance in maintaining progress of inclusive education in the country.

\subsubsection{RECOMMENDATIONS FOR POLICY FORMULATION}

A policy directing the Ministry of Education, Science and Technology on importance of providing in schools the necessary needs in provision of education for students with visual impairment should be formulated. Its analysis should show types of needs to be provided in schools, their relevance in provision of inclusive education, 
and how to motivate education providers designing the needs and demonstrate how to apply them to facilitate lesson understanding to students.

\subsubsection{RECOMMENDATIONS FOR FURTHER RESEARCH}

Researches on supply of special teaching and learning needs in inclusive schools should be conducted. They will investigate means for getting the needs, their types and relevance in facilitating learning to VI students as well as how to apply and supply them to schools.

\section{REFERENCES}

Bryman, A. (2016). Quantity and Quality in Social Research. In Quantity and Quality in Social Research. Montreal-Canada: Routledge Company Limited.

Chawala, J. F. (2011). An Evaluation of Psychosocial Services To Children With Visual Impairment In Tanzania. In MASP Dissertation). UDSM.

Cohen, L., Manion, L., \& Marrison, K. (2011). Research Methods In Education. Research Methods In Education. London: Routledge Falmer.

Cowan, C. (2015). Program Information And Administrative Resources. Program Information And Administrative Resources: Tips For Working With Blind Students. St. Austin: 1100 West 45th.

Creswell, J. W. (2014). Quantitative, And Mixed Methods Approaches. Research Design: Qualitative, Quantitative, And Mixed Methods Approaches.

Hoy, W. K., \& miskel, C. G. (2008). Educational Administration. In Educational Administration, Theory, Research, And Practice (8th Ed.). New York: Mcgraw-Hill.

Karuhawe, C. D. G. (2020). Provision Of Quality Inclusive Education For Students With Visual Impairment In Tanzania Secondary Schools. Provision OfQuality Inclusive Education For Students With Visual Impairment In Tanzania Secondary Schools.

King, N. A. S. (2014). Investigation Of Factors Hindering Quality Education In Secondary Schools In Mbeya. Mbeya-Tanzania. In Investigation Of Factors Hindering Quality Education In Secondary Schools In Mbeya. Mbeya-Tanzania.

Kisanga, S. E. (2017). Disability And Rehabilitation: Assistive Technology. Educational Barriers Of Students With Sensory Impairment And Their Coping Strategies In Tanzanian Higher Education Institutions.

Kisanga, S. E. (2019). "It Is Not Our Fault. We Are The Victims Of The Education System ": Assessment Of The Accessibility Of Examinations And Information For Students With Visual Impairment In Tanzania. The Journal of The International Association Of Special Education, 19(01), 15-26.

Kisanga, S. E., \& Kisanga, D. H. (2020). The role of assistive technology devices in fostering the participation and learning of students with visual impairment in higher education institutions in Tanzania. Disability and Rehabilitation: Assistive Technology, 110. Retrieved from https://dx.doi.org/10.1080/17483107.2020.1817989 10.1080/ 17483107.2020.1817989

Kisanga, S. E., \& Richards, G. (2018). Teaching pedagogies in Tanzanian inclusive educational settings: Do they respond to diverse needs? Voices from students with visual impairment. British Journal of Visual Impairment, 36(3), 026461961878091026461961878091. Retrieved from https://dx.doi.org/10.1177/0264619618780914 


\section{$10.1177 / 0264619618780914$}

Lahav, O., Schloerb, D. W., \& Srinivasan, M. A. (2015). Orientation And Mobility: Virtual Involvements For People Who Are Visually Impaired Integrated Into An Orient And Mobility Programme. A Journal of Visual Impairment And Blindness, 109(1), 43-53.

Lincoln, Y. S., \& \&amp;guba, E. G. (1985). Naturalistic Inquiry. In Naturalistic Inquiry. California: Sage. Newbury Park, Publications.

Lugome, G. G. (2018). Academic Performance Impediments Among Students With Visual Impairment In Inclusive Secondary Schools In Tanzania. Academic Performance Impediments Among Students With Visual Impairment In Inclusive Secondary Schools In Tanzania.

Methods Of Data Collection In Qualitative Research: Interviews And Focus Groups. (2008). British Dental Journal, 204, 22-22.

Mfangavo, K. I. (2015). A Dissertation In Master Of Education In Administration, Planning And Policy Studies Of The Open University Of Tanzania. In The Influence Of Students Enrollment On Effective Utilization Of Available Teaching-Learning Resources In Community Secondary Schools: A Case Of Arusha City Council In Tanzania. (A Dissertation In Master of Education In Administration, Planning And Policy Studies of The Open University of Tanzania). Dar Es Salaam: OUT.

Mgumba, B. F. (2018). ccess To Counselling Services For Students With Visual Impairment In The Selected Universities In Tanzania. In Access To Counselling Services For Students With Visual Impairment In The Selected Universities In Tanzania: Focus On Social -Psychological And Educational Needs. Dar Es Salaam: UDSM.

Mizikaci, F. (2018). A Systems Approach To Program Evaluation Model For Quality In Higher Education. In A Systems Approach To Program Evaluation Model For Quality In Higher Education. Bucharest, Romania: UNESCO-CEPES.

Omvig, J. H. (1999). Empowering The Blind Student. In Empowering The Blind Student. The Braille Monitor: Part 2 of 2 Parts. Baltimore, Maryland: National Federation Of The Blind.

Parvin, S. (2018). Social Inclusion Of Visually Impaired Students Studying In A Comprehensive Secondary Mainstream School In The South Of England. International Journal of Scientific And Research Publications, 5(2), 1-5.

POSSI, M. K., \& MILINGA, J. R. (2017). Special and Inclusive Education in Tanzania: Reminiscing the Past, Building the Future. Educational Process: International Journal, 6(4), 5573. Retrieved from https://dx.doi.org/10.22521/edupij.2017.64.4 10.22521/edupij 2017.64.4

Said, Z. (2017). The Implementation Of The National Inclusive Education Strategy In Primary Schools In Morogoro Municipality, Tanzania. (Master Of Education In Administration. Planning And Policy Studies.

Taylor, J. (2016). Educating Students With Visual Impairment For Inclusion In Society. In Educating Students With Visual Impairment For Inclusion In Society. A Paper On The Inclusion Of Students With Visual Impairment. New York: American Foundation For The Blind.

Watch, H. R. (2017). Barriers To Secondary Education In Tanzania. Human Right Watch Report On Tanzania.

Yin, R. K. (2011). Qualitative Research From Start To Finish. In Qualitative Research From Start To Finish. New York: The Guilford Press. 